\title{
Penggunaan Media Gambar dalam Meningkatkan Hasil Belajar pada Pembelajaran IPA di SDK Ende 3
}

\author{
Alfonita Timu $^{1}$, Yuliani Sepe Wangge ${ }^{2}$, Finsensius Mbabho ${ }^{3}$ \\ 1,2,3 Program Studi PGSD Universitas Flores Ende. \\ Jalan Samratulangi, Kelurahan Pupire, Ende, Flores, Indonesia \\ ${ }^{*}$ Corresponding Author: Alfonitatimu@gmail.com
}

\begin{abstract}
Info Artikel Abstract
Sejarah Artikel:

Diterima: $12 / 12 / 2019$

Direvisi: $11 / 02 / 2020$

Disetujui: 24/02/2020

Keywords: Image

Media, learning

learning

This research aims to determine how the use of image media to improve learning outcomes on $I P A$ learning in the SDK Ende 3. This research is class action research (CAR). The research subject is grade IV students. Data collection techniques are conducted through observation, test, and documentation. The results showed that student learning results were improved. On the pre test, the average class value was 64.57 and the classification was $34.28 \%$ and the average grade rate was increased to 89,42 with the classical dictancy of $100 \%$ on the I cycle. Based on the research results can be concluded that the use of image media can improve learning outcomes on natural science learning in the SDK Ende 3.
\end{abstract}

\begin{abstract}
Abstrak
Penelitian ini bertujuan untuk mengetahui bagaimana penggunaan media gambar dalam meningkatkan hasil belajar pada pembelajaran IPA di SDK Ende 3. Penelitian ini adalah penelitian tindakan kelas (PTK). Subjek penelitian adalah siswa kelas IV. Teknik pengumpulan data dilakukan melalui observasi, test, dan dokumentasi. Hasil penelitian menunjukkan bahwa hasil belajar siswa mengalami peningkatan. Pada pre test, nilai rata-rata kelas adalah 64,57 dan ketuntasan klasikalnya adalah 34,28\% dan nilai rata-rata kelas meningkat menjadi 91,14 dengan ketuntasan klasikal sebesar 100\% pada siklus I. Berdasarkan hasil penelitian dapat diambil kesimpulan bahwa penggunaan media gambar dapat meningkatkan hasil belajar pada pembelajaran IPA di SDK Ende 3.
\end{abstract}

\footnotetext{
"Alamat korespondensi:

Program Studi Pendidikan Guru Sekolah Dasar

Fakultas Keguruan dan Ilmu Pendidikan Universitas Flores

() 2020 Program Studi PGSD Universitas Flores

Kampus III Universitas Flores, Jln. Samratulangi,

Email: primagistrauniflor@gmail.com

Kelurahan Paupire, Ende, NTT

E-mail: Alfonitatimu@gmail.com
} 


\section{PENDAHULUAN}

Pendidikan dimaknai sebagai semua tindakan yang mempunyai efek pada perubahan watak, kepribadian, pemikiran dan perilaku. Pendidikan merupakan proses pembebasan peserta didik dari ketidaktahuan, ketidakmampuan, ketidakberdayaan, ketidakbenaran, ketidakjujuran, dan dari buruknya hati, akhlak, dan keimanan. Oleh karena itu, pendidikan tidak boleh menjadikan manusia asing terhadap dirinya dan asing terhadap hati nuraninya.

Pendidikan harus mampu menyatukan sikap, pemikiran, perlilaku, hati nurani dan keimanan menjadi satu kesatuan yang utuh (Mulyanasa, 2012:1). Tujuan pendidikan pada dasarnya mengantarkan peserta didik menuju perubahan-perubahan tingkah laku baik intelektual, moral maupun sosial agar dapat hidup mandiri sebagai makhluk individu dan makhluk sosial. Berhasil dan tidaknya pencapaian tujuan pendidikan tergantung pada proses belajar.

Keberhasilan suatu proses pembelajaran pada umumnya terletak pada pendekatan, model pembelajaran, media maupun metode tertentu sesuai dengan karakteristik pendidikan itu sendiri. Guru sebagai tenaga pendidik harus mampu mengembangkan keterampilan dan kreativitasnya sehingga tujuan pembelajaran dapat tercapai.

Tercapai tidak nya tujuan pembelajaran salah satunya bisa dilihat dari hasil belajar yang diperoleh peserta dididk. Rusman (2012) menyatakan bahwa hasil belajar merupakan sejumlah pengalaman yang diperoleh peserta didik yang mencakup ranah kognitif, afektif dan psikomotorik. Belajar tidak hanya berpatok pada penguasaan konsep teori mata pelajaran saja tetapi juga pada penguasaan kebiasaan, kesenangan, minat, bakat dan harapan. Sejalan dengan Rusman, Jufri (2013) juga menyatakan bahwa hasil belajar merupakan kemampuan yang dapat diamati dalam diri seseorang.

Jufri dalam bukunya yang berjudul belajar dan pembelajaran sains (2013) menyatakan bahwaada tiga ranah dalam hasil belajar yaitu kognitif, afektif dan psikomotor.
Ranah kognitif ini meliputi penguasaan konsep, ide, pengetahuan faktual yang berkaitan dengan keterampilan-keterampilan pengetahuan.

Ada enam kategori umum dalam ranah kognitif yaitu:

a) Pengetahuan (Knowledge). Hasil belajar pada kategori ini paling rendah tetapi menjadi prasyarat bagi pencapaian hasil belajar yang lebih tinggi;

b) (b)Pemahaman (comprehension). Pemahaman diekspresikan dalam bentuk kemampuan memahami informasi, memanfaatkan dan mengekstrapolasi pengetahuan dalam konteks baru, menjelaskan makna, menginterpretasi fakta, dan memprediksi sesuatu. Hasil belajar berupa pemahaman dapat dibedakan menjadi tiga kategori yaitu pemahaman terjemahan (menerjemahkan bahasa atau istilah), pemahaman penafsiran (menghubungkan bagian-bagian dari suatu kejadian, membedakan yang pokok dan yang bukan pokok), pemahaman ekstrapolasi (kemampuan melihat makna yang tersirat, dapat membuat asumsi tentang konsekuensi dari suatu kejadian);

c) Aplikasi (Application) adalah kemampuan untuk menggunakan pengetahuan atau abstraksi meliputi ide, teori, metode, konsep, rumus, hukum, prinsip dan pedoman yang dimiliki pada situasi konkret atau situasi khusus;

d) Analisis (Analysis) adalah usaha memilah suatu konsep atau struktur menjadi unsur-unsur atau bagianbagian sehingga jelas hierarki atau susunannya. Analisis merupakan kecakapan yang kompleks yang memanfaatkan kecakapan dari ketiga tipe hasil belajar yang sebelumnya;

e) Sintesis (Synthesis) adalah kemampuan yang menyatukan unsur- 
unsur atau bagian-bagian kedalam satu kesatuan yang utuh;

f) Evalusi (Evaluation) merupakan kategori hasil belajar kognitif yang tertinggi. Evalusi merupakan kemampuan memberikan keputusan nilai sesuatu yang mungkin dilihat dari tujuan, gagasan, cara bekerja, pemecahan, metode dan materi.

Ranah afektif menurut Jufri (2013) berkaitan dengan sikap dan nilai. Ranah afektif ini juga dibedakan menjadi lima aspek, yaitu:

a) Penerimaan (receiving). Kategori ini meliputi kepekaan dalam menerima rangsangan (stimulus) dari luar yang datang kepada dirinya dalam bentuk masalah, situasi atau kejadian;

b) Merespons (Responding) adalah reaksi yang diberikan oleh seseorang terhadap stimulus yang datang dari luar;

c) Menilai (Valuing). Kemampuan menilai gejala atau stimulus yang diterima oleh peserta didik. Dalam hal ini termasuk kesediaan menerima nilai, latar belakang atau pengalaman untuk menerima nilai dan kesepakatan terhadap nilai trsebut;

d) Mengorganisasi (Organization). Kemampuan mengorganisasi yakni kemampuan mengembangkan nilainalai kedalam suatu sistem termasuk hubungan suatu nilai dengan nilai yang lain;

e) Internalisasi Nilai (Characterization by Value) Internalisasi nilai yakni keterpaduan semua sistem nilai yang dimiliki oleh seseorang yang mempengaruhi pola kepribadian dari tingkah lakunya.

Ranah psikomotor menurut Jufri (2013) merupakan ranah yang berkenaan dengan hasil belajar yang diekspresikan dalam bentuk keterampilan menyelesaikan tugas-tugas manual dan gerakan fisik atau kemampuan bertindak. Dalam ranah psikomotor ini ada empat aspek utama yaitu: gerakan, manipulasi, komunikasi dan mengkreasi

Berdasarkan pernyataan tersebut diatas maka dapat diambil kesimpulan bahwa hasil belajar merupakan perubahan perilaku dalam diri seseorang secara menyeluruh yang dinilai oleh guru setelah proses pembelajaran dilaksanakan dan perubahan itu bukan hanya pada satu aspek saja tetapi terpadu secara utuh.

Keberhasilan belajar sangat dipengaruhi oleh beberapa faktor. Faktor tersebut dapat dikelompokan menjadi dua kelompok yaitu faktor Internal dan faktor eksternal. Faktor pertama adalah faktor Internal dari dalam diri peserta didik yang berpengaruh terhadap hasil belajar diantaranya adalah kecakapan, minat, bakat, usaha, motivasi, perhatian, kelemahan, dan kesehatan serta kebiasaan pesrta didik.

Minat belajar berkaitan dengan seberapa besar individu merasa suka atau tidak suka terhadap satuan materi yang dipelajari peserta didik. Minat inilah yang harus dimunculkan sejak awal dalam diri peserta didik. Minat, motivasi dan perhatian peserta didik dapat dikondisikan oleh guru.

Ada dua faktor Internal yang mempengaruhi hasil belajar yaitu: (a) Faktor Fisiologis, seperti kondisi kesehatan yang prima, tidak dalam keadaan lelah dan capek dan tidak dalam keadaan cacat jasmani. Hal ini dapat mempengaruhi peserta didik dalam menerima pembelajaran; (b) Faktor Psikologis adalah faktor dalam diri peserta didik masingmasing memiliki kondisi psikologis yang berbeda-beda, hal ini dapat mempengaruhi hasil belajarnya. Faktor psikologis ini meliputi: intelegensi (IQ), perhatian minat, bakat, motifasi, kognitif dan daya nalar peserta didik.

Faktor kedua adalah faktor Eksternal, Faktor dari luar diri peserta didik yang mempegaruhi hasil belajar diantaranya adalah lingkungan fisik dan non fisik termasuk suasana dalam kelas dalam belajar, seperti riang gembira, menyengkan, lingkungan sosial budaya, lingkungan keluarga, program sekolah ( termasuk komite sekolah), guru, pelaksanaaan pembelajaran dan teman sekolah. 
Ada dua faktor eksternal yang mempengaruhi hasil belajar, yaitu: (a) Faktor Lingkungan. Lingkungan dapat mempengaruhi hasil belajar peserta didik. Faktor lingkungan meliputi lingkungan fisik dan lingkungan social; (b) Faktor Instrumental, faktor Instrumental adalah faktor yang keberadaan dan penggunaannya dirancang sesuai dengan hasil belajar yang diharapkan. Faktor ini diharapkan dapat berfungsi sebagai sarana untuk mencapai tujuan belajar yang di harapkan, seperti kurikulum, sarana dan guru.

Berdasarkan hal tersebut diatas, maka guru memegang peranan yang sangat penting bagi peningkatan hasil belajar. Selain kreatif, guru harus memiliki keterampilan yang memadai. Salah satu keterampilan yang harus dimiliki oleh seorang guru adalah keterampilan mengembangkan media pembelajaran yang sesuai dengan materi yang ingin diajarkan.

Sundayana (2013) mengatakan bahwa Media adalah manusia, materi, atau kejadian yang membangun kondisi yang membuat peserta didik mampu memperoleh pengetahuan, keterampilan dan sikap. Dalam pengetahuan ini, guru, buku teks dan lingkungan sekolah merupakan media.

Pengertian media dalam proses belajar mengajar cenderung diartikan sebagai alat-alat grafis, photografis untuk menangkap, memproses dan menyusun kembali informasi visual atau verbal. Media merupakan sumber belajar atau wahana fisik yang mengandung materi di lingkungan peserta didik yang dapat merangsan peserta didik untuk belajar.

Jadi, media pembelajaran adalah sumber belajar yang digunakan oleh guru dalam melaksanakan proses pembelajaran dalam bentuk gambar, foto dan video yang dapat merangsang peserta didik untuk belajar agar dapat mencapai tujuan pembelajaran yang diharapkan.

Ada banyak jenis media pembelajaran, salah satunya adalah media gambar. Menurut Sadirman, dkk (2011:29) Media gambar merupakan bahasa yang umum, yang dapat dimengerti dan dinikmati dimana-mana. Gambar pada dasarnya membantu mendorong peserta didik untuk membangkitkan semangat dan minat dalam belajar. Membantu peserta didik untuk mampu berbahasa, kegiatan seni dan pernyataan kreatif dalam bercerita serta membantu mengingat isi materi yang telah dipelajari.

Sejalan dengan pendapat Sadirman, Arsyad (2013:89) menyatakan bahwa media gambar dapat memperlancar pemahaman dan daya ingat peserta didik dan menumbuhkan minat peserta didik serta memberikan hubungan antara isi materi pelajaran dengan dunia nyata.

Berdasarkan pendapat para ahli tersebut diatas, maka dapat disimpulkan bahwa media pembelajaran, dalam hal ini adalah media gambar merupakan media memiliki manfaat yang cukup banyak dalam menumbuhkan minat dan semangat bagi peserta didik dalam belajar. Melihat manfaat tersebut diatas maka guru selaku pendidik perlu meningkatkan keterampilannya dalam memgembangkan media pembelajaran.

Media pembelajaran yang di rancang dengan baik mampu membangkitkan minat anak untuk belajar. Namun kenyataan yang ditemukan peneliti ketika melakukan observasi awal di SDK Ende 3 adalah kurang maksimalnya guru dalam merancang dan memanfaatkan media pembelajaran. hal ini menyebabkan rendahnya minat belajar peserta didik. Rendahnya minat belajar berpengaruh pada motivasi dan aktivitas belajar yang akhirnya mempengaruhi hasil belajar, khususnya hasil belajar IPA pada peserta didik kelas IV

Sehubungan dengan permasalahan tersebut diatas maka upaya yang harus dilakukan untuk mengatasi permasalahan yang berkaitan dengan hasil belajar adalah dengan menggunakan media pembelajaran yang tepat. Penggunaan media pembelajaran yang tepat sudah terbukti dapat meningkatkan hasil belajar. Ini dapat dilihat dari hasil penelitian terdahulu.

Penelitian yang dilakukan oleh Rahman (2011) yang berjudul "Penggunaan Media Gambar Dalam Meningkatkan Hasil Belajar Siswa Kelas VI SD Negeri I Peusangan Bireuen Aceh", Nuryati (2013) dengan judul 
penelitiannya "Penggunaan Media Gambar Untuk Meningkatkan Hasil Belajar Siswa Dalam Pembelajaran Ilmu Pengetahuan Sosial Di Kelas IV SDN Ujung VIII/33 Surabaya", dan Harahap (2016) dengan judul penelitiannya tentang "Penggunaan Media Gambar Untuk Meningkatkan Hasil Belajar IPS Siswa", dari ketiga penelitian tersebut diatas, menunjukkan bahwa media gambar merupakan salah satu alternatif yang dapat digunakan untuk meningkatkan hasil belajar. Berdasarkan hal tersebut, maka peneliti melakukan penelitian menggunakan media gambar untuk mengatasi permasalahan hasil belajar.

Penelitian yang dilakukan peneliti adalah penelitian tindakan kelas. Adapun perbedaan penelitian ini dari penelitian sebelumnya dilihat dari hasil belajar. Hasil belajar yang ingin ditingkatkan melalui penggunaan media gambar disini adalah hasil belajar IPA bukan hasil belajar IPS, dan penelitian ini dilakukan pada siswa kelas IV di SDK Ende 3.

Penelitian ini dilakukan berdasarkan permasalahan yang ditemukan peneliti pada saat melalukan observasi awal. Tujuan dari penelitian ini adalah untuk meningkatakan hasil belajar IPA melalui penggunaan media gambar pada siswa kelas IV di SDK Ende 3.

\section{METODE PENELITIAN}

Penelitian ini merupakan penelitian tindakan kelas (PTK). Menurut Tampubolon (2013) Penelitian Tindakan Kelas merupakan penelitian praktis di dalam kelas yang bertujuan untuk memperbaiki kualitas proses pembelajaran, meningkatkan hasil belajar, dan menemukan model pembelajaran inovatif untuk memecahkan masalah yang dialami oleh pendidik dan peserta didik.

PTK yang dilakukan peneliti merujuk pada prosedur penelitian yang dikembangkan oleh Kurt Lewin, dimana penelitian merupakan penelitian siklus yang terdiri dari empat tahap yaitu tahap perencanaan, pelaksanaan, pengamatan dan refleksi. Tahap pertama yaitu tahap perencanaan (Planning). Tahap ini bertujuan untuk menghasilkan rancangan pembelajaran bermutu yang mampu membelajarkan peserta didik secara afektif dan membangkitkan partisipasi aktif peserta didik dalam pembelajaran.

Perencanaan terkait dengan penemuan dan menempatkan masalah sehingga dengan berdasarkan masalah yang ada, peneliti dapat memecahkan masalah melalui penggunaan metode pembelajaran, teknik strategi pembelajaran, media dan materi pembelajaran yang semuanya itu termasuk dalam perangkat pembelajaran yaitu: Rencana Pelaksanaan Pembelajaran (RPP) dan Silabus pembelajaran

Tahap kedua adalah tahap pelaksanaan Tindakan (Acting), Implementasi tindakan dan prinsipnya, merupakan realisasi rencana perlakuan yang dituangkan dalam RPP yang telah disusun. Oleh karena itu pelaksanaan tindakan diupayakan tidak menyimpang dari pelaksanaaan perilakuan.Tahap ketiga adalah tahap pengamatan (Observation). Tahap ini dilakukan bersamaan dengan tahap kedua. Pengamatan, observasi atau monitoring dapat dilakukan sendiri oleh peneliti. Pada saat monitoring peneliti perlu mencatat peristiwa atau hal yang terjadi di dalam kelas.

Tahap ke empat adalah tahap refleksi (Reflecting). Refleksi adalah pembuatan merenungkan atau menirukan sesuatu atau upaya Evaluasi yang dilakukan oleh kolaborator atau partisipasi yang terkait dengan suatu PTK yang dilakukan adanya diskusi terhadap berbagai masalah yang terjadi di kelas penelitian. Dengan demikian refleksi dapat dilakukan sesudah adanya tindakan dan hasil observasi. Berdasarkan refleksi itu pula merupakan suatu perbaikan tindakan

Penelitian ini berlangsung pada bulan Mei 2019. Subjek penelitian adalah siswa kelas IV SDK Ende 3 yang berjumlah 35 orang. Teknik pengumpulan data dilakukan melalui observasi, tes dan dokumentasi. Data dianalisis dengan cara deskriptif kualitatif dan kuantitatif.

Adapun bentuk analisis persentase ketuntasan belajar siswa secara perseorangan adalah sebagai berikut: 


$$
P=\frac{F}{A} \times 100 \%
$$

Keterangan:

$\mathrm{P}=$ Persentase keberhasilan

$\mathrm{F}=$ Jumlah skor yang diperoleh

$\mathrm{A}=$ Jumlah skor maksimal

Sedangkan untuk menghitung persentase klasikal dengan kriteria ketuntasan kelompok (klasikal), adalah siswa yang dianggap telah tuntas belajarnya atau dalam arti siswa yang nilai tesnya telah mencapai atau lebih dari nilai KKM yang telah ditetapkan dihitung dengan menggunakan rumus:

$$
\begin{aligned}
& \mathrm{K}=\frac{\mathrm{A}}{\mathrm{B}} \times 100 \% \\
& \text { Keterangan } \\
& \mathrm{K}=\text { Persentase keberhasilan klasikal } \\
& \mathrm{A}=\text { Jumlah siswa yang memperoleh } \\
& \quad \text { nilai } \geq 70 \\
& \mathrm{~B}=\text { Jumlah seluruh siswa }
\end{aligned}
$$

(dimodifikasi dari Arikunto, 2010: 246)

Pembelajaran melalui penggunaan media gambar dikatakan berhasil dan tidak perlu dilanjutkan ke siklus berikutnya adalah apabila $85 \%$ peserta didik mencapai ketuntasan belajar $\geq 70$.

\section{HASIL DAN PEMBAHASAN}

\section{A. Hasil Penelitian}

Tujuan dari penelitian ini adalah untuk meningkatkan hasil belajar pada pembelajaran IPA melalui media gambar pada siswa kelas VI SDK Ende 3. Hasil penelitian dapat dilihat pada Tabel 1 berikut ini.

Tabel 1. Nilai hasil belajar IPA

\begin{tabular}{cccc}
\hline No & $\begin{array}{c}\text { Nilai hasil } \\
\text { belajar }\end{array}$ & Pra Siklus & Siklus I \\
\hline 1 & Jumlah skor & 2260 & 3130 \\
2 & Rata-rata & 64,57 & 91,14 \\
3 & Tuntas & $34,28 \%$ & $100 \%$ \\
4 & Tidak Tuntas & $65,71 \%$ & - \\
\hline
\end{tabular}

Berdasarkan data pada tabel 1, diketahui bahwa persentase ketuntasan belajar sebelum diberi tindakan sebesar 34,28\% dengan nilai rata-rata sebesar 64,57. Pada siklus I meningkat menjadi $100 \%$ dengan nilai ratarata sebesar 91,14. Hasil pada siklus I sudah memenuhi target yang ingin dicapai yaitu $\geq$ 70. Dengan demikian penelitian dengan menggunakan media gambar telah berhasil meningkatkan hasil belajar IPA pada siswa kelas IV SDK Ende 3.

\section{B. Pembahasan}

Peningkatan hasil belajar yang terlihat pada tabel 1, tidak terlepas dari prosedur pelaksanaan penelitian yang menerapkan media gambarl. Langkah penerapan ini melalui beberapa tahap. Tahap perencanaan, tahap pelaksanaan, tahap observasi dan tahap refleksi. Tahap pertama adalah tahap perencanaaan. Pada tahap ini peneliti membuat perencanaan yang dilakukan berdasarkan observasi awal yang dilakukan peneliti pada tanggal 10 Mei 2019 dan tanggal 11 Mei 2019.

Pada observasi awal peneliti menemukan bahwa permasalahan hasil belajar yang dialami peserta didik kelas IV di SDK Ende 3 disebabkan karena kurang maksimalnya penggunaan media pembelajaran dan kurangnya kreativitas guru dalam mengembangkan media pembelajaran yang menarik bagi peserta didik. Hal ini berdampak pada kurangnya minat belajar IPA dan rendahnya motivasi belajar, sehingga menyebabkan rendahnya hasil belajar.

Pada tahap perencanaan peneliti merancang perangkat pembelajaran IPA sesuai dengan materi yang diajarkan yaitu tentang sumber daya alam dengan menggunakan media gambar. Selain Recana Pelaksanaan Pembelajaran (RPP), silabus dan lembar kerja siswa (LKS),pada tahap ini peneliti juga menyusun lembar observasi sebagai bahan untuk mengukur keterlaksanaan pembelajaran baik oleh guru maupun siswa dan juga sebagai bahan acuan untuk melakukan refleksi. Setelah semua persiapan dilakukan, peneliti melanjutkan ke tahap berikutnya yaitu tahap pelaksanaan

Tahap kedua yaitu tahap pelaksanaan dilakukan mulai tanggal 13 Mei 2019. Tidakan yang dilakukan pada tahap ini sesuai dengan perangkat pembelajaran yang telah dibuat. Peneliti berperan sebagai guru dan menberikan pengajaran pada peserta didik dengan materi sumber daya alam. Peneliti 
menjelaskan tentang sumber daya alam yang ada di lingkungan sekitar. Peneliti menjelaskan perbedaan sumber daya laut, sungai, hutan dan pegunungan melalui media gambar yang sudah disiapkan. Setelah menjelaskan secara singkat tentang sumber daya alam berdasarkan lingkungannya, peneliti mengelompokkan peserta didik secara acak menjadi beberapa kelompok.

Kelompok yang sudah dibagi tersebut diberikan tugas untuk berdiskusi menyelesaikan LKS yang ada. Setelah selesai masing-masing kelompok diberikan kesempatan untuk mempresentasikan hasil diskusinya. Diakhir pembelajaran guru memberikan evaluasi pada masing-masing siswa.

Tahap ketiga adalah tahap observasi. Tahap ini dilakukan bersamaan dengan tahap pelaksanaan tindakan. Adapun observasi dilakukan oleh dua observer yaitu rekan peneliti dan guru kelas IV. Observasi yang dilakukan berkaitan dengan observasi aktivitas guru dan observasi akivitas peserta didik. Berdasarkan data hasil pengamatan diketahui bahwa observasi aktivitas guru berada pada kategori baik dengan persentase sebesar 78,12\%. Dan hasil observasi aktivitas siswa berada pada kategori baik dengan persentase $84,09 \%$.

Tahap keempat adalah tahap refleksi. Tahap refleksi merupakan tahap akhir dari penelitian ini. Berdasarkan hasil pengamatan maka diketahui bahwa aktivitas guru selama proses pembelajaran berada pada kategori baik. Guru selaku pendidik sudah melaksanakan pembelajaran sesuai dengan perangkat pembelajaran yang dirancangnya, tahap demi tahap dilakukan secara runtut sehingga pembelajaran terlaksana dengan baik. Dari hasil pengamatan aktivitas guru selama pembelajaran berlangsung, nilai akhir yang diperoleh adalah $78,12 \%$. Hal ini menunjukan bahwa aktivitas guru termasuk dalam kategori baik

Dan data hasil observasi terhadap aktivitas peserta didik sebesar $84,09 \%$ dengan kategori baik. Dari hasil pengamatan terhadap aktivitas peserta didik pada saat proses belajar mengajar berlangsung peserta didik sudah berperan secara aktif dalam setiap kegiatan yang dilakukan di dalam kelas. Mereka mengikuti apa yang diarahkan guru selama pembelajaran. Media gambar yang disediakan guru mampu menarik minat mereka untuk memperhatikan apa yang dijelaskan guru.

Meningkatnya minat mempengaruhi aktivitas mereka pada saat kegiatan diskusi berlangsung. Diskusi kelompok berjalan dengan baik. Siswa aktif bertanya, menjawab pertanyaan dan sudah berani untuk menyatakan pendapat mereka terkait dengan materi yang diajarkan. Mereka mampu menyelesaikan LKS yang diberikan dan mampu mempertanggungjawabkan hasil diskusi melalui presentasi di depan kelas.

Refleksi terkait hasil belajar berdasarkan data yang diperoleh yaitu apabila dibandingkan dengan pretest yang nilai rataratanya sebesar 64,57 dengan ketuntasan klasikal sebesar $34,28 \%$ dimana dari 35 orang peserta didik hanya 12 orang saja yang tuntas, 23 lainnya belum memenuhi KKM. maka pada siklus pertama ini nilai rata-rata mengalami peningkatan dimana ketuntasan klasikal mencapai $100 \%$ dengan rata-rata kelas sebesar 91,14. Dimana dari 35 orang peserta didik terdapat 26 orang yang memperoleh nilai evaluasi diatas 80 . Berdasarkan hasil tersebut maka penelitian ini tidak dilanjutkan ke siklus berikutnya karena hasil yang diperoleh sudah mencapai ketuntasan yang diharapkan.

\section{SIMPULAN DAN SARAN}

Hasil penelitian pada siklus I menunjukkan bahwa penggunaan media gambar dapat meningkatkan hasil belajar IPA pada siswa kelas IV di SDK Ende 3. Pembelajaran menggunakan media gambar mampu menarik minat peserta didik untuk belajar IPA, sehingga hal ini berpengaruh pada hasil belajar.

Oleh karena itu, saran peneliti bagi guru IPA adalah dalam memilih media pembelajaran harus disesuaikan dengan materi pembelajaran, agar tujuan pembelajaran dapat tercapai. 


\section{DAFTAR PUSTAKA}

Arikunto,S. 2010. Prosedur Penelitian Suatu Pendekatan Praktik. Jakarta: Rineka Cipta.

Arsyad. 2013. Media pembelajaran. Jakarta : PT Raja Grafindo

Harahap, D. 2016. Penggunaan Media Gambar Untuk Meningkatkan Hasil Belajar IPS Siswa. Jurnal Pendidikan Dan Kependidikan Vol 1, No 1.

Jufri, 2013. Belajar dan Pembelajaran Sains. Bandung: PT Pustaka Reka Cipta

Mulyanasa, D. 2012. Pendidikan Bermutu dan Berdaya Saing. Jakarta : PT Remaja Rosdakarya

Nuryati, Tutik. 2013. Penggunaan Media Gambar Untuk Meningkatkan Hasil Belajar Siswa Dalam Pembelajaran Ilmu Pengetahuan Sosial Di Kelas IV SDN Ujung VIII/33 Surabaya. Jurnal Penelitian Pendidikan Guru Sekolah Dasar.

Rahman, Aisyah A. 2011. Penggunaan Media Gambar Dalam Meningkatkan Hasil Belajar Siswa Kelas VI SD Negeri I Peusangan Bireuen Aceh. Madrasah, Vol. 3 No. 2.

Rusman,2012. Belajar dan Pembelajaran Berbasis Komputer. Gerlong Tengah: Alfabeta

Sadirman, dkk.2011. Media pendidikan. Jakarta : PT Raja Grafindo

Sundayana, 2013. Media Pembelajaran. Bandung:Alfabeta

Tampubolon. 2013. Penelitian Tindakan Kelas. Jakarta : PT. Gelora Aksara Pratama 